\title{
Competitiveness of Uzbek agrarian foreign trade - different regional trade blocs and the most significant trade partners
}

\author{
Akhmadjon Ortikov \\ Department of Economics, Faculty of Economics and Management, \\ CULS Prague \\ ortikov@pef.czu.cz. \\ Luboš Smutka \\ Department of Economics, Faculty of Economics and Management, \\ CULS Prague \\ smutka@pef.cru.cr.

\section{Irena Benešová} \\ Department of Economics, Faculty of Economics and Management, \\ CULS Prague \\ benesova@pef.cru.cr.
}

Abstract. Agriculture is one of the leading and largest economic sectors in the nation of Uzbekistan. The share of employees in the agricultural sector is $33 \%$ of the population. The annual growth rate of the agricultural sector is $1.7 \%$, and it accounts for $18 \%$ of GDP. Agriculture provides jobs for approximately 15 million people, many of whom are part-time workers. During the years 2000 2018 , the value of agrarian trade turnover increased from cc 520 million USD to 2.8 billion USD. This paper examines Uzbek foreign trade in agricultural products from the following perspectives: trade balance of Uzbekistan and international competitiveness. The intention of the paper is to determine changes in the character of agricultural trade. Changes in the product structure are identified, and individual changes are explained. The comparative advantages are analyzed according to different groups of countries (Asian countries without CIS countries, CIS without Asian countries, EU28 without other European countries, other European countries without EU and CIS countries, and developing countries). Agrarian trade competitiveness and territorial and commodity structure changes are analyzed for the last 19 years (2000-2018). The commodity structure of agricultural trade is analyzed on the basis of the standard Harmonized System. The source of information in the article is UN COMTRADE. The analysis is based on the following method and indexes: "product mapping approach" method, Herfindahl-Hirschman index, 
Lafay index, and the trade balance index. In addition, some other statistical characteristics are applied: geomean, chain index, basic index, import/export coverage ratio, etc. Uzbek agricultural exports are competitive with regard to Asian and CIS countries, and limited when compared with other territories.

Keywords: agrarian trade, agricultural products and foodstuffs, Uzbekistan, partners, competitiveness, changes, institutional comparative advantage, balance, products mapping.

\section{JEL Classification: Q13, Q17}

\section{INTRODUCTION}

In the second decade of the 21 st century, the world economy is undergoing significant changes in its overall picture, which we were accustomed to seeing during the period of so-called hyper-globalization. It is the result of fundamental changes in the economic and geopolitical framework of global development and the transformation process that globalization processes have brought about as a result of profound structural changes.

The essential factors that have emerged in international relations include the slowing down of globalization processes, or even in certain areas, the opposite process of de-globalization, both at the global and regional level.

In this context, professional literature appeared the idea of the return of so-called geopolitics and geoeconomics to the practice of world economic, but also in wider sense political relations. It aims to use trade policy instruments to achieve the strategic geopolitical goals of individual powers and their geopolitical ambitions (Benešová, Novotná, Šánová, \& Laputková, 2016a; Veebel \& Markus, 2018).

Because of increasing power competition of "superpowers" small economies are under the permanent pressure. Very good example of such a situation is Uzbekistan - former post Soviet country. Its economy is heavily dependent on CIS (Commonwealth of Independent states) countries and especially Russian Federation. The trade between these countries is influenced by the basic relationship defined by Head, Mayer and Ries (2010) based on post-colonial ties and further extended to post-Soviet republics (Mazhikeyev \& Edwards, 2013; Mazhikeyev, Edwards, \& Rizov, 2015). At the same time, a typical centerperiphery relationship could be applied to the Russia-other relationship (Furusawa \& Konishi, 2007; Kowalczyk \& Wonnacott, 1992; Puga, 2001). When comparing 2000 and 2015, there is a greater degree of interdependence between countries, especially those linked to Russia. This is pointed out by Myant and Drahokoupil (2008). At the same time, the structure of foreign trade of individual countries is gradually changing. There is a greater interconnection between individual geographical units. From the perspective of openness of the economy, it can also be said that Tajikistan, together with Uzbekistan, is among the countries that are closest to autarchy in 2015. Similar conclusions were reached by Bose (2005), Cameron et al. (2012) and Korosteleva (2016), who add that the export structure of these countries is also a problem. The possibility to diversify trade territorial structure concentration is rather limited because of negative influence of traditional trade partners (Benesova et al., 2016b; Remeikiene et al., 2018).

Uzbekistan is not member of the World Trade Organization. Uzbekistan's most important export partners include Switzerland, China, Russia, Turkey and Kyrgyzstan. In the case of imports, China, Russia, South Korea, Kazakhstan and Turkey are among the most important trading partners of Uzbekistan. China is an important trading partner for most Central Asian countries. One of the reasons is the large amount of mineral resources found in these countries (Bohr, 2004; Cobanli, 2014; Linn, 2012). Norling and Swanstrom (2007) point out that trade between these countries is becoming continental rather than 
regional and favors broader ties. In the case of foreign trade between countries, there are also significant differences in the geographic structure of the market, where China and other Asian countries are an important trading partner for the Central Asian Republics (Chiaruttini, 2014; Linn, 2012; Spechler \& Spechler, 2013; Yun \& Park, 2012).

Uzbekistan has similar structural problems to Russia. These challenges include unfinished transformation, over-reliance on natural resources, lack of innovation and low productivity (Connolly, 2015; Hartwell, 2013).

Agrarian foreign trade has been chosen, to demonstrate the difficult situation of Uzbek foreign trade development and ambitions. The article is devoted to the position of Uzbek agricultural and foodstuff product exports in the international market (Csaki \& Nash, 1999). Uzbekistan is one of the main producers of fruits and vegetables in the CIS member countries. After a protocol establishing a free trade zone was signed between the Republic of Uzbekistan and the CIS in 2013, the trade turnover of the agricultural products of Uzbekistan significantly increased. The main goal of the Protocol is the effort of Uzbekistan to unify trade regimes in relation to CIS, and to foster existing cooperation within the customs union of the former Soviet countries (Smutka et al., 2015a). The territorial structure of Uzbek agricultural and foodstuff exports in the period of 2000 to 2018 was heavily focused on Asian and CIS countries. Only in 2000, the share of CIS members in agricultural exports and imports reached $83.3 \%$ and $33.6 \%$, respectively. In the same year - the share of other Asian countries in agri-food exports and imports reached cc $7.4 \%$ respectively $13 \%$. Later on (in 2018), the share of CIS countries was reduced in favour of other Asian countries. While CIS countries share in exports and imports was reduced to $66 \%$ respectively $69 \%$, the share of other Asian countries increased up to $32 \%$, respectively $14 \%$. The dominant positions are kept by Russia, Kazakhstan and Belarus. On the other hand, the share of exports to Russia is decreasing, and Kazakhstan has become an extremely important trade partner for Uzbek agrarian exports within the last few years. (Ilyina, D. FAO 2016). The Russian Federation share in Uzbek agricultural exports reached about $87.3 \%$ in 2000 and $25.4 \%$ in 2018. The share of Kazakhstan in Uzbek agricultural exports reached about $1.06 \%$ in 2000 and $55.8 \%$ in 2018. This article analyzes trends in the major changes in the territorial and commodity structure of the agricultural sector of Uzbekistan from 2000 to 2018. In the analyzed time period, the post-Soviet countries and the Republic of Uzbekistan significantly changed their trade strategies and policies. A negative feature of Uzbek agrarian trade is a much faster increase in the value of imports compared to the value of exports. As a result, the negative trade balance is constantly increasing.

\section{METHODOLOGY}

The article analyzes the export potential of Uzbekistan in the international market of agricultural products for the last two decades (2000-2018). The article is focused on trade competitiveness in relation to individual groups of trade partners of Uzbekistan. Trade performance is analyzed in relation to the following groups: Asian countries (without the CIS), European countries (without CIS and EU28), CIS countries (without Asian countries), and other European countries (without EU28). The classification of agricultural products in the article uses the Harmonized System (according to UN Comtrade methodology), which divides agricultural trade into 24 aggregations (for details, see Table 1). The article calculates all values at current prices in USD. 
The list of Harmonized commodity aggregations in the analysis (HS)

\begin{tabular}{|c|c|c|c|}
\hline HS01 & Live animals & HS13 & $\begin{array}{l}\text { Lac gums, resins and other vegetable saps and } \\
\text { extracts }\end{array}$ \\
\hline HSO2 & Meat and edible meat offal & HS14 & $\begin{array}{l}\text { Vegetable plaiting materials vegetable products not } \\
\text { elsewhere specified or included }\end{array}$ \\
\hline HS03 & $\begin{array}{l}\text { Fish and crustaceans, molluscs and other aquatic } \\
\text { invertebrates }\end{array}$ & HS15 & $\begin{array}{l}\text { Animal or vegetable fats and oils and their cleavage } \\
\text { products prepared edible fats animal or vegetable } \\
\text { waxes }\end{array}$ \\
\hline HSO4 & $\begin{array}{l}\text { Dairy produce birds' eggs natural honey edible } \\
\text { products of animal origin, not elsewhere specified or } \\
\text { included }\end{array}$ & HS16 & $\begin{array}{l}\text { Preparations of meat, of fish or of crustaceans, } \\
\text { molluscs or other aquatic invertebrates }\end{array}$ \\
\hline HS05 & $\begin{array}{l}\text { Products of animal origin, not elsewhere specified or } \\
\text { included }\end{array}$ & HS17 & Sugars and sugar confectionery \\
\hline HSO6 & $\begin{array}{l}\text { Live trees and other plants bulbs, roots and the like } \\
\text { cut flowers and ornamental foliage }\end{array}$ & HS18 & Cocoa and cocoa preparations \\
\hline HS07 & Edible vegetables and certain roots and tubers & HS19 & $\begin{array}{l}\text { Preparations of cereals, flour, starch or milk pastry } \\
\text { cooks' products }\end{array}$ \\
\hline HS08 & Edible fruit and nuts peel of citrus fruit or melons & HS20 & $\begin{array}{l}\text { Preparations of vegetables, fruit, nuts or other parts } \\
\text { of plants }\end{array}$ \\
\hline HS09 & Coffee, tea, mate and spices & HS21 & Miscellaneous edible preparations \\
\hline HS10 & Cereals & HS22 & Beverages, spirits and vinegar \\
\hline HS11 & $\begin{array}{l}\text { Products of the milling industry malt starches inulin } \\
\text { wheat gluten }\end{array}$ & HS23 & $\begin{array}{l}\text { Residues and waste from the food industries } \\
\text { prepared animal fodder }\end{array}$ \\
\hline HS12 & $\begin{array}{l}\text { Oil seeds and oleaginous fruits miscellaneous grains, } \\
\text { seeds and fruit industrial or medicinal plants and } \\
\text { fodder }\end{array}$ & HS24 & Tobacco and manufactured tobacco substitutes \\
\hline
\end{tabular}

Source: COMTRADE database, 2019

The article analyzes the allocation of comparative advantages in relation to the Asian market, as well as to the rest of the world (CIS members, other European countries (without EU28), the European Union (EU28) and developing countries). The following methods are used to achieve the above-mentioned results: Herfindahl-Hirschman index, Lafay index, trade balance index and product mapping. The Herfindahl-Hirschman index uses a common measure for market concentration and the determination of market competitiveness. The LFI and TBI indices only provide limited knowledge of trade competitiveness development. The "product mapping method" defines the whole process of profiling the commodity structure of the agrarian foreign trade of Uzbekistan. This approach is based on a combination of both above-mentioned indicators (a similar approach has already been tested by Maitah et al., 2016; Bielik et al., 2013; Rezbova et al., 2014; Svatos et al., 2010; Borak et al., 2018; Braha et al., 2019; Ferto 2017, 2018; Jambor et al., 2017; Wajda-Lichy \& Kawa, 2018; Bilan et al., 2018; Kozlovskyi et al., 2018). The Lafay index (Lafay, 1992) analysis is used to help provide information on bilateral trade relations between countries and regions. The use of the Herfindahl-Hirschman index is a common indicator of market concentration and is used to determine market competitiveness. HHI is calculated by squaring the market share of each country competing in the market and then summing the results. It can range from zero to 10,000. A market with an HHI of less than 1,500 is considered a competitive market, an HHI of 1,500 to 2,500 is a moderately concentrated marketplace, and an HHI of 2,500 or more is a highly concentrated marketplace. Using the LFI index, we may observe the difference between the general normalized trade balance and each item's normalized trade balance. The LFI index, by taking imports into account, allows controlling for intra-industry trade and re-export streams. Defined in this way, it is superior to the traditional Revealed Comparative Advantages index (Balassa, 1965). Thus, the LFI index is used to eliminate the influence of cyclical factors that may affect the amount of trade streams in the short term, and to focus on bilateral trade relations between regions and countries. 
Contrarily, negative values indicate de-specialization (Zaghini, 2003; Smutka et al., 2015b). While the LFI index is focused on the analysis of the development of competitiveness, the TBI index analyzes the development of the trade balance. A country is defined as a "net importer" in a specific product group if the TBI value is negative, and a "net exporter" if the TBI value is positive. (Widodo, 2009; Ischukova, Smutka, 2013 and 2014).

Figure 1 represents the matrix for the allocation of the whole set of exported commodities into 4 groups in accordance with two selected indicators (LFI and TBI). The data sources for individual analysis are the State Committee of the Republic of Uzbekistan on Statistics and UN COMTRADE.

The Herfindahl-Hirschman index is calculated by squaring the market share of each country competing in the market and then summing up the results. The Herfindahl-Hirschman index is formulated as follow:

$$
\mathrm{HHI}=S_{1}^{2}+S_{2}^{2}+S_{3}^{2}+\ldots . S_{n}^{2}
$$

Where: $S_{n}$ is the market share percentage of country n expressed as a whole number, not a decimal.

The next method used in this paper is the product mapping method. This method determines the whole process of profiling the commodity structure of the agrarian foreign trade of Uzbekistan:

Table 1

Modified product mapping scheme

\begin{tabular}{|c|c|c|}
\hline \multirow{2}{*}{ Lafay index } & $\begin{array}{c}\text { Group B: } \\
\text { Comparative Advantage Net- } \\
\text { importer } \\
\text { (LFI }>0 \text { and TBI }<0)\end{array}$ & $\begin{array}{c}\text { Group A: } \\
\text { Comparative Advantage Net- } \\
\text { exporter } \\
(\text { LFI }>0 \text { and TBI }>0)\end{array}$ \\
\cline { 2 - 3 } & $\begin{array}{c}\text { Group D: } \\
\text { Comparative disadvantage Net- } \\
\text { importer } \\
(\text { LFI }<0 \text { and TBI }<0)\end{array}$ & $\begin{array}{c}\text { Group C: } \\
\text { Comparative disadvantage Net- } \\
\text { exporter } \\
(\text { LFI }<0 \text { and TBI }>0)\end{array}$ \\
\hline $\begin{array}{c}\text { Uzbek Agrarian Foreign Trade } \\
\text { Commodity Structure }\end{array}$ & \multicolumn{2}{|c|}{ Trade Balance Index } \\
\hline
\end{tabular}

Source: own modification and processing (2019)

The trade balance index (TBI) by Lafay (1992) is an indicator of export-import activities.

The TBI is mainly used to analyze whether a country specializes in imports (as a net importer) or exports (as a net exporter) for a specific group of products, and is simply formulated as follows:

$$
\text { TBIij }=(x i j-m i j) /(x i j+m i j)
$$

where TBIij denotes the trade balance index of country $\mathrm{i}$ for product $\mathrm{j}$; xij and mij represent exports and imports of group of products $j$ by country $i$, respectively. (Lafay, 1992). Values of the index range from -1 to +1 . At the extremes, the TBI equals -1 if a country only imports; in contrast, the TBI equals +1 if a country only exports. Indeed, the index is not defined when a country neither exports nor imports. A country is termed a "net exporter" if the TBI reaches positive values and "net importer" in a specific product if the TBI values are negative (Widodo, 2009; Zaghini, 2003).

By considering imports, the Lafay index (LFI) allows controlling for intra-industry trade and reexport flows (Lafay, 1992). In this sense, it surpasses the traditional index of Revealed Comparative Advantages (Balassa, 1965).

Since comparative advantages are structural, by definition it is extremely important to exclude the influence of cyclical factors that may affect the amount of trade flows in the short term. 
The Lafay index takes these effects into account, given the difference between the normalized trade balance of each position and the overall normalized trade balance. Finally, the Lafay index weighs the contribution of each product according to its importance in trading.

For a given country, $i$, and for any given product $j$, the Lafay index is defined as:

$$
L F I_{j}^{i}=100\left(\frac{x_{j}^{i}-m_{j}^{i}}{x_{j}^{i}+m_{j}^{i}}-\frac{\sum_{j=1}^{N}\left(x_{j}^{i}-m_{j}^{i}\right)}{\sum_{j=1}^{N} x_{j}^{i}+m_{j}^{i}}\right) \frac{x_{j}^{i}+m_{j}^{i}}{\sum_{l=1}^{N} x_{j}^{i}+m_{j}^{i}}
$$

where xij and $\mathrm{m}$ ij are exports and imports of product $j$ of country $i$, towards and from the rest of the world, respectively, and $\mathrm{N}$ is the number of items.

Positive values of the Lafay index indicate the existence of comparative advantages in a given item; the larger the value, the higher the degree of specialization. (Zaghini, 2003).

The RSCA index is a common decreasing commons transformation of the Balassa index (Balassa, 1991) or revealed comparative advantage (RCA). In practice, the Balassa index is a generally accepted method for analyzing the transaction date (Bielik, Smutka and Svatos, 2013; Dalum, Laursen and Villumsen, 1998; Maitah, Rezbova and Smutka, 2016; Rezbova, Smutka and Purkrabek, 2014; Cieślik et al., 2018). RCA is based on export performance and observed trade patterns. This index was used to determine the most important areas and product groups for the region's export trade. It is used in the international economy to calculate the relative advantage or disadvantage of a particular country in a particular class of goods or services. RCA measures a country's exports of a commodity (or industry) relative to its total exports and to the corresponding exports of a set of countries.

$$
\mathrm{RCA}=(\mathrm{Xij} / \mathrm{Xit}) /(\mathrm{Xnj} / \mathrm{Xnt})=(\mathrm{Xij} / \mathrm{Xnj}) /(\mathrm{Xit} / \mathrm{Xnt})
$$

where $\mathrm{X}$ represents exports, $\mathrm{i}$ is a country, $\mathrm{j}$ is a commodity (or industry), $\mathrm{t}$ is a set of commodities (or industries) and $\mathrm{n}$ is a set of countries. The RSCA index is characterized as follows:

$$
\text { RSCA }=(\text { RCAit-1) } /(\text { RCAij }+1)
$$

The values of the RSCAij index range from minus one to one. RSCAij greater than zero implies that country $i$ has a comparative advantage in a group of products $j$. In contrast, RSCAij less than zero implies that country $i$ has a comparative disadvantage in a group of products $j$ (Svatos and Smutka, 2012).

This article presents an extended version of an article presented at the Agrarian Perspectives conference under the title Comparative advantage: Products mapping of Uzbekistan's agricultural exports (Ortikov and Vacek, 2018).

\section{EMPIRICAL RESULTS AND DISCUSSION}

The agrarian trade of Uzbekistan is concentrated on CIS members, Central Asian and European countries (Table 2). The most dominant role is played by CIS members, Asian countries and EU members. But during the analyzed time period the role of individual partners changed. The total value of agricultural trade performance recorded significant growth. The nominal value of exports increased from about 250 mil. USD up to about 1.1 bil. USD. The value of imports recorded growth from 271 mil. USD up to 1.7 bil. USD. The total value of the negative agri-food trade balance increased from 18.6 mil. USD up to about 583 mil. USD. The problem of Uzbek agrarian trade value development is connected to much lower inter-annual growth rate of export value in comparison to inter-annual growth of import value. Because of much higher imports' dynamics in comparison to exports, Uzbekistan recorded the significant reduction of export/import coverage ratio. 
Uzbek agrarian exports' concentration - by regional groups (HHI index)

\begin{tabular}{|l|c|c|c|c|}
\hline \multirow{2}{*}{ Groups } & \multicolumn{2}{c|}{2000} & \multicolumn{2}{c|}{2018} \\
\cline { 2 - 5 } & Market share & HHI index & Market share & HHI index \\
\hline Asia (without CIS countries) & $7.4 \%$ & 54.76 & $31.7 \%$ & 1004.9 \\
\hline Africa & $0.0 \%$ & 0 & $0.0 \%$ & \\
\hline EU 28 & $7.0 \%$ & 49 & $1.8 \%$ & 3.2 \\
\hline Other European countries (without EU and & $1.2 \%$ & 1.44 & $0.0 \%$ & \\
CIS) & $83.5 \%$ & 6972.25 & $66.2 \%$ & 4382.4 \\
\hline CIS (without Asian countries) & $0.9 \%$ & 0.81 & $0.3 \%$ & 0.1 \\
\hline North America & $0.0 \%$ & 0 & $0.0 \%$ & \\
\hline Latin America & $0.0 \%$ & 0 & $0.0 \%$ & \\
\hline Australia and Oceania & $100.0 \%$ & 7078.26 & $100.0 \%$ & 5390.7 \\
\hline World & & & & \\
\hline
\end{tabular}

Source: own processing, 2019

During the analyzed time period export/import coverage ratio significantly decreased from $93 \%$ to $65 \%$.

In 2000, the Asian share in Uzbek agricultural exports and imports reached about $7.4 \%$ and $31.7 \%$, respectively. In the same year - the share of EU28 in agricultural exports and imports reached about 7\% and $1.8 \%$, respectively and the share of CIS members in agricultural exports and imports reached $83.5 \%$ and $66.2 \%$, respectively. The most dominant role was played by the Russian Federation, Belarus and Tajikistan (Table 3). In 2000, Russian Federation's share in Uzbek agricultural exports and imports reached about $87.3 \%$ and $25.43 \%$, respectively. The share of Belarus in agricultural exports and imports reached about $3.4 \%$ and $1.24 \%$, respectively and the share of Tajikistan in agricultural exports and imports reached $2.4 \%$ and $1.4 \%$, respectively.

Table 3

Uzbek agrarian exports' concentration - by CIS countries (HHI index)

\begin{tabular}{|l|c|c|c|c|}
\hline \multirow{2}{*}{ Groups } & \multicolumn{2}{|c|}{2000} & \multicolumn{2}{c|}{2018} \\
\cline { 2 - 5 } & Market share & HHI index & Market share & HHI index \\
\hline Azerbaijan & $0.04 \%$ & 0.00 & $0.75 \%$ & 0.5625 \\
\hline Belarus & $3.37 \%$ & 11.36 & $1.24 \%$ & 1.5376 \\
\hline Moldova & $0.01 \%$ & 0.00 & $0.06 \%$ & 0.0036 \\
\hline Armenia & $0.11 \%$ & 0.01 & $0.08 \%$ & 0.0064 \\
\hline Georgia & $1.47 \%$ & 2.16 & & \\
\hline Kazakhstan & $1.06 \%$ & 1.12 & $55.86 \%$ & 3120.3396 \\
\hline Kyrgyzstan & $1.91 \%$ & 3.65 & $12.31 \%$ & 151.5361 \\
\hline Russian Federation & $87.32 \%$ & 7624.78 & $25.43 \%$ & 646.6849 \\
\hline Tajikistan & $2.34 \%$ & 5.48 & $1.42 \%$ & 2.0164 \\
\hline Turkmenistan & $1.51 \%$ & 2.28 & $1.45 \%$ & 2.1025 \\
\hline Ukraine & $0.86 \%$ & 0.74 & $1.40 \%$ & 1.96 \\
\hline Total & $100.00 \%$ & 7651.58 & $100.00 \%$ & 3926.7496 \\
\hline
\end{tabular}

Source: own processing, 2019

The share of Kazakhstan in agricultural exports and imports reached 1\% and 59\%, respectively. 
Table 4

Uzbek agrarian foreign trade value development between 2000 and 2018 in USD

\begin{tabular}{|c|c|c|c|c|c|c|c|c|c|}
\hline 2000 & Africa & $\begin{array}{l}\text { Asia (without } \\
\text { GIS countries) }\end{array}$ & $\begin{array}{c}\text { Australia and } \\
\text { Oceania }\end{array}$ & CIS & EU 28 & Latin America & $\begin{array}{c}\text { North } \\
\text { America }\end{array}$ & $\begin{array}{c}\text { Other } \\
\text { European } \\
\text { countries } \\
\text { (without EU } \\
\text { and CIS) } \\
\end{array}$ & World total \\
\hline Export & & 18677323 & & 210867285 & 17749020 & 95 & 2181042 & 3092804 & 252567569 \\
\hline Import & & 35743330 & & 91372459 & 141937313 & 57994 & 1793607 & 336619 & 271241322 \\
\hline Balance & & -17066007 & & 119494826 & -124188293 & -57899 & 387435 & 2756185 & -18673753 \\
\hline $\begin{array}{c}\text { Balance/ } \\
\text { Export }\end{array}$ & $0.00 \%$ & $-91.37 \%$ & $0.00 \%$ & $56.67 \%$ & $-699.69 \%$ & $-60946.32 \%$ & $17.76 \%$ & $89.12 \%$ & $-7.39 \%$ \\
\hline 2018 & Africa & $\begin{array}{l}\text { Asia (without } \\
\text { CIS countries) }\end{array}$ & $\begin{array}{c}\text { Australia and } \\
\text { Oceania }\end{array}$ & CIS & EU 28 & Latin America & $\begin{array}{l}\text { North } \\
\text { America }\end{array}$ & $\begin{array}{c}\text { Other } \\
\text { European } \\
\text { countries } \\
\text { (without EU } \\
\text { and CIS) } \\
\end{array}$ & World total \\
\hline Export & 356832 & 350697619 & & 731889267 & 19612179 & 35221 & 2821751 & 281193 & 1105694062 \\
\hline Import & 5131002 & 237673958 & 1180138 & 1174946324 & 190393528 & 66130720 & 5291454 & 7901691 & $\begin{array}{c}1688648 \\
815 \\
\end{array}$ \\
\hline Balance & -4774170 & 113023661 & -1180138 & -443057057 & -170781349 & -66095499 & -2469703 & -7620498 & -582954753 \\
\hline $\begin{array}{c}\text { Balance/ } \\
\text { Export }\end{array}$ & $-1337.93 \%$ & $32.23 \%$ & $-3350.67 \%$ & $-60.54 \%$ & $-870.79 \%$ & $-187659.35 \%$ & $-87.52 \%$ & $-2710.06 \%$ & $-52.72 \%$ \\
\hline $\begin{array}{l}\text { Export Basic } \\
\text { index } \\
2018 / 2000\end{array}$ & 0.02 & 18.78 & - & 3.61 & 1.10 & 370.75 & 1.29 & 0.09 & 4.52 \\
\hline $\begin{array}{c}\text { Import Basic } \\
\text { index } \\
2018 / 2000 \\
\end{array}$ & 0.14 & 6.65 & 20.35 & 12.90 & 1.34 & 1140.3 & 2.95 & 23.47 & 6.23 \\
\hline
\end{tabular}

Source: COMTRADE database, 2019 and own calculations.

Table 5

Uzbek agrarian foreign trade value development by CIS countries between 2000 and 2018 in USD

\begin{tabular}{|c|c|c|c|c|c|c|c|c|c|c|c|}
\hline 2000 & Balance & Export & Import & $\begin{array}{c}\text { Balance/ } \\
\text { Export }\end{array}$ & 2018 & Balance & Export & Import & $\begin{array}{c}\text { Balance/ } \\
\text { Export }\end{array}$ & $\begin{array}{c}\text { Export } \\
\text { Basic index } \\
2015 / \\
2000 \\
\end{array}$ & $\begin{array}{c}\text { Import } \\
\text { Basic index } \\
2015 / \\
2000\end{array}$ \\
\hline Azerbaijan & 65553 & 93673 & 28120 & $70 \%$ & Azerbaijan & 5528197 & 2701010 & 2827187 & $51 \%$ & 59 & 96 \\
\hline Belarus & 6922800 & 7103200 & 180400 & $97 \%$ & Belarus & 9147774 & 21686357 & -12538583 & $-137 \%$ & 1 & 120 \\
\hline Moldova & -1045314 & 30437 & 1075751 & $-3434 \%$ & Moldova & 414787 & 316070 & 98717 & $24 \%$ & 14 & 0 \\
\hline Armenia & 237680 & 237680 & & $100 \%$ & Armenia & 608295 & 40320 & 567975 & $93 \%$ & 3 & \\
\hline Georgia & 2784457 & 3092442 & 307985 & $90 \%$ & & & & & & & \\
\hline Kazakhstan & -71249100 & 2232000 & 73481100 & $-3192 \%$ & Kazakhstan & $\begin{array}{c}411787 \\
557 \\
\end{array}$ & $\begin{array}{c}612408 \\
366\end{array}$ & $\begin{array}{c}-200620 \\
809\end{array}$ & $-49 \%$ & 184 & 8 \\
\hline Kyrgyzstan & 2648145 & 4031855 & 1383710 & $66 \%$ & Kyrgyzstan & 90772582 & 1999282 & 88773300 & $98 \%$ & 23 & 1 \\
\hline $\begin{array}{c}\text { Russian } \\
\text { Federation }\end{array}$ & $\begin{array}{c}173034 \\
616 \\
\end{array}$ & $\begin{array}{c}184119 \\
106 \\
\end{array}$ & 11084490 & $94 \%$ & $\begin{array}{c}\text { Russian } \\
\text { Federation }\end{array}$ & $\begin{array}{c}187484 \\
593 \\
\end{array}$ & $\begin{array}{c}400116 \\
086\end{array}$ & $\begin{array}{c}-212631 \\
493 \\
\end{array}$ & $-113 \%$ & 1 & 36 \\
\hline Tajikistan & 4850000 & 4931000 & 81000 & $98 \%$ & Tajikistan & 10483127 & 371576 & 10111551 & $96 \%$ & 2 & 5 \\
\hline Turkmenistan & 3010600 & 3190410 & 179810 & $94 \%$ & Turkmenistan & 10679195 & 2531545 & 8147650 & $76 \%$ & 3 & 14 \\
\hline Ukraine & -1764611 & 1805482 & 3570093 & $-98 \%$ & Ukraine & 10299639 & $\begin{array}{c}132775 \\
712\end{array}$ & $\begin{array}{c}-122476 \\
073\end{array}$ & $-1189 \%$ & 6 & 37 \\
\hline Total & $\begin{array}{c}119494 \\
826\end{array}$ & $\begin{array}{c}210867 \\
285\end{array}$ & 91372459 & $57 \%$ & Total & $\begin{array}{c}737205 \\
746\end{array}$ & $\begin{array}{c}1174946 \\
324\end{array}$ & $\begin{array}{c}-437740 \\
578\end{array}$ & $-59 \%$ & 3 & 13 \\
\hline
\end{tabular}

Source: COMTRADE database, 2019 and own calculations.

As can be seen in tables 4 and 5, the current agricultural trade performance of Uzbekistan is heavily focused on CIS and Asian countries. Those partners represent nearly $98 \%$ of export value and $84 \%$ of import value in 2018. The key aspect of Uzbek agrarian trade is its competitiveness (especially low-price competitiveness). Based on volume (tons) and value (total value and unit value) analysis, bulk commodities (e.g. vegetables, fruits) could be considered the main driver of agricultural export growth. Another very specific feature of Uzbek agri-food trade is its concentration on post-Soviet countries. The markets of those countries represent the key territory for export-oriented activities. And mutual trade 
agreements (preferential trade agreements and free-trade zones) could be considered the key element supporting national export ambitions.
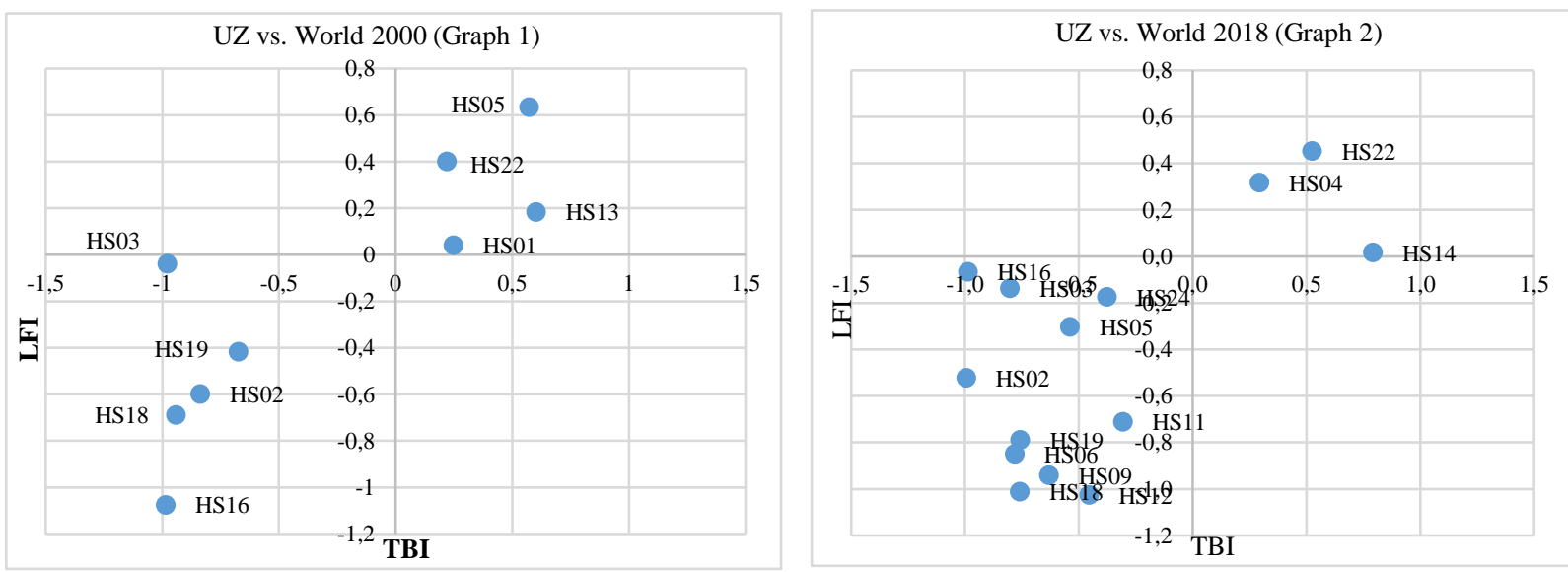

Graphs 1 - 2. Uzbek agrarian exports' comparative advantages distribution - traditional and modified "Product mapping approach"

Source: own processing, 2019
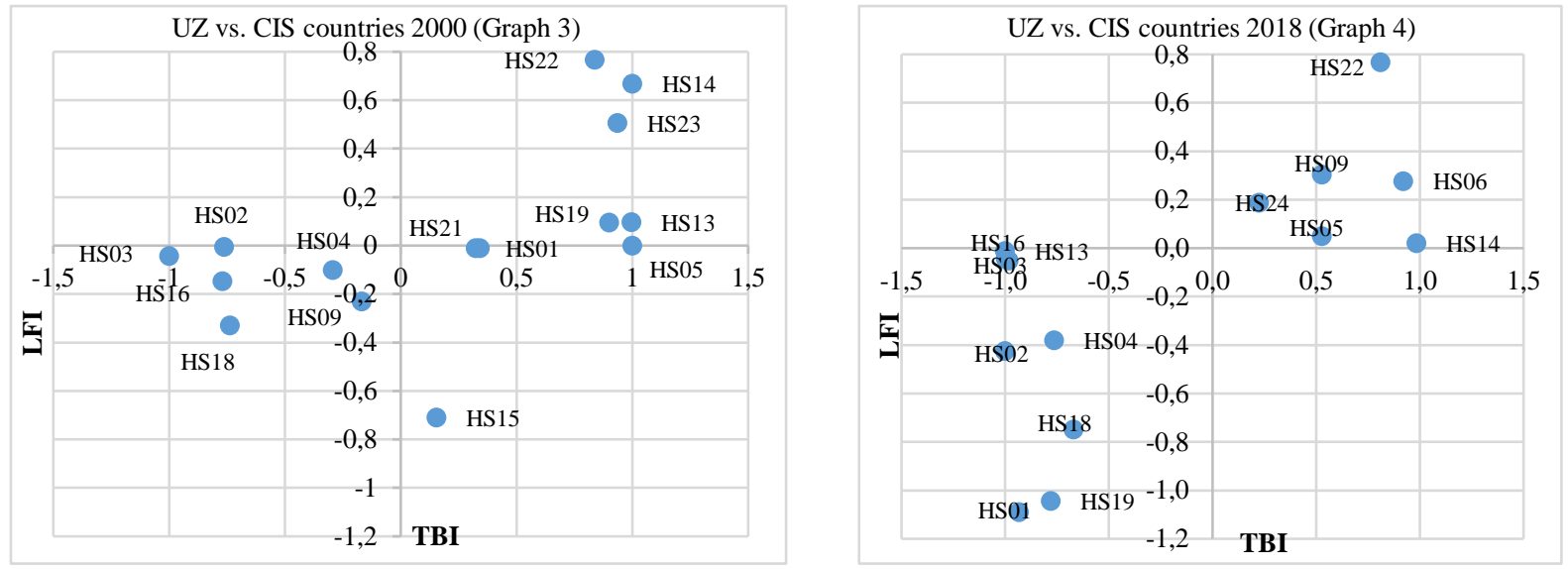

Graphs 3 - 4. Uzbek agrarian exports' comparative advantages distribution - traditional and modified "Product mapping approach"

Source: own processing, 2019

The existence of comparative advantages is proved through the application of LFI and TBI indices, taking into consideration only agricultural trade performance. The above-mentioned graphs provide an overview related to the global competitiveness of individual Uzbek agrarian trade items (graphs 1 and 2) and CIS members (graphs 3 and 4). The graphs provide a different overview of the modified product mapping approach. The results provided by the modified approach deliver a more accurate overview of the distribution of the comparative advantages of Uzbek agrarian exports. The number of items located in groups B and C is significantly reduced, and the whole commodity structure is divided into two groups, A (with comparative advantages) and $\mathrm{D}$ (without comparative advantages). The modified approach is able to specify in more detail the current level of Uzbek agrarian trade competitiveness and competitiveness development. Using this applied approach, it is evident that the structure of Uzbek agrarian commodity 
trading has been significantly changing its character. The commodity structure is still looking for its optimal state (for details see tables 6 and 8 (global) and also tables 7 and 9 (for CIS countries)).

Table 6

Uzbek agrarian trade commodity structure in 2000 (traditional product mapping) in USD

\begin{tabular}{|c|c|c|c|c|c|c|c|c|c|}
\hline & & & & & \multicolumn{5}{|c|}{ All trade transactions worldwide 2000} \\
\hline B-2000 & Import & Share in import & Export & Share in export & A-2000 & Import & Share in import & Export & Share in export \\
\hline & & & & & HS01 & 285088 & $0.11 \%$ & 473396 & $0.19 \%$ \\
\hline & & & & & HS05 & 1148989 & $0.42 \%$ & 4227646 & $1.69 \%$ \\
\hline & & & & & HS06 & 153620 & $0.06 \%$ & 5850545 & $2.35 \%$ \\
\hline & & & & & HS07 & 6534242 & $2.41 \%$ & 32139297 & $12.88 \%$ \\
\hline & & & & & HS08 & 1053268 & $0.39 \%$ & 85853445 & $34.41 \%$ \\
\hline & & & & & HS12 & 2739601 & $1.01 \%$ & 14509999 & $5.82 \%$ \\
\hline & & & & & HS13 & 296551 & $0.11 \%$ & 1193263 & $0.48 \%$ \\
\hline & & & & & HS14 & 160607 & $0.06 \%$ & 16741308 & $6.71 \%$ \\
\hline & & & & & HS20 & 1173581 & $0.43 \%$ & 27575339 & $11.05 \%$ \\
\hline & & & & & HS22 & 3113466 & $1.15 \%$ & 4876474 & $1.95 \%$ \\
\hline & & & & & HS23 & 609150 & $0.22 \%$ & 13047628 & $5.23 \%$ \\
\hline & & & & & HS24 & 9079735 & $3.35 \%$ & 29672985 & $11.89 \%$ \\
\hline & & & & & Total & 26347898 & $9.72 \%$ & 236161325 & $94.66 \%$ \\
\hline D-2000 & Import & Share in import & Export & Share in export & $\mathrm{C}-2000$ & Import & Share in import & Export & Share in export \\
\hline HSO2 & 3589988 & $1.33 \%$ & 318945 & $0.13 \%$ & & & & & \\
\hline HS03 & 211647 & $0.08 \%$ & 2247 & $0.00 \%$ & & & & & \\
\hline HS04 & 16914352 & $6.24 \%$ & 217660 & $0.09 \%$ & & & & & \\
\hline HS09 & 14385851 & $5.31 \%$ & 763809 & $0.31 \%$ & & & & & \\
\hline HS10 & 64044224 & $23.64 \%$ & 2446313 & $0.98 \%$ & & & & & \\
\hline HS11 & 16295797 & $6.01 \%$ & 305017 & $0.12 \%$ & & & & & \\
\hline HS15 & 16986672 & $6.27 \%$ & 5214505 & $2.09 \%$ & & & & & \\
\hline HS16 & 5877851 & $2.17 \%$ & 45180 & $0.02 \%$ & & & & & \\
\hline HS17 & 91835500 & $33.90 \%$ & 2819949 & $1.13 \%$ & & & & & \\
\hline HS18 & 3858285 & $1.42 \%$ & 115100 & $0.05 \%$ & & & & & \\
\hline HS19 & 2868718 & $1.06 \%$ & 561099 & $0.22 \%$ & & & & & \\
\hline HS21 & 7716554 & $2.85 \%$ & 503978 & $0.20 \%$ & & & & & \\
\hline Total & $\begin{array}{c}244585 \\
439\end{array}$ & $90.28 \%$ & 13313802 & $5.34 \%$ & & & & & \\
\hline
\end{tabular}

Source: own processing, 2019

Table 7

Uzbek agrarian trade commodity structure by CIS countries in 2000 (traditional product mapping approach) in USD

\begin{tabular}{|c|c|c|c|c|c|c|c|c|c|}
\hline \multicolumn{10}{|c|}{ Trade transactions by CIS countries 2000} \\
\hline B-2000 & Import & Share in import & Export & Share in export & A-2000 & Import & Share in import & Export & Share in export \\
\hline & & & & & HS05 & & & 710 & $0.00 \%$ \\
\hline & & & & & HS06 & 7751 & $0.01 \%$ & 5618346 & $2.66 \%$ \\
\hline & & & & & HS07 & 187543 & $0.21 \%$ & 31618947 & $14.99 \%$ \\
\hline & & & & & HS08 & 55679 & $0.06 \%$ & 83986594 & $39.83 \%$ \\
\hline & & & & & HS12 & 1415650 & $1.55 \%$ & 10389548 & $4.93 \%$ \\
\hline & & & & & HS13 & 969 & $0.00 \%$ & 483874 & $0.23 \%$ \\
\hline & & & & & HS14 & & $0.00 \%$ & 3341257 & $1.58 \%$ \\
\hline & & & & & HS19 & 28796 & $0.03 \%$ & 544212 & $0.26 \%$ \\
\hline & & & & & HS20 & 74269 & $0.08 \%$ & 26718344 & $12.67 \%$ \\
\hline & & & & & HS22 & 427779 & $0.47 \%$ & 4821699 & $2.29 \%$ \\
\hline & & & & & HS23 & 90600 & $0.10 \%$ & 2738382 & $1.30 \%$ \\
\hline & & & & & HS24 & 1126880 & $1.23 \%$ & 29289288 & $13.89 \%$ \\
\hline & & & & & Total & 3415916 & $3.74 \%$ & 199551201 & $94.63 \%$ \\
\hline D-2000 & Import & Share in import & Export & Share in export & C-2000 & Import & Share in import & Export & Share in export \\
\hline $\mathrm{HSO2}$ & 12561 & \begin{tabular}{|l|l|}
$0.01 \%$ \\
\end{tabular} & 1700 & $0.00 \%$ & HS01 & 156907 & \begin{tabular}{|l|l|}
$0.17 \%$ \\
\end{tabular} & 307596 & $0.15 \%$ \\
\hline HSO3 & 91077 & $0.10 \%$ & & $0.00 \%$ & HS15 & 3755936 & $4.11 \%$ & 5123879 & $2.43 \%$ \\
\hline HS04 & 286333 & $0.31 \%$ & 156595 & $0.07 \%$ & HS21 & 196665 & $0.22 \%$ & 401748 & $0.19 \%$ \\
\hline HSO9 & 721258 & $0.79 \%$ & 513028 & $0.24 \%$ & & & & & \\
\hline
\end{tabular}




\begin{tabular}{|c|c|c|c|c|c|c|c|c|c|}
\hline HS10 & 60859807 & $66.61 \%$ & 1536569 & $0.73 \%$ & & & & & \\
\hline HS11 & 14774369 & $16.17 \%$ & 305000 & $0.14 \%$ & & & & & \\
\hline HS16 & 337807 & $0.37 \%$ & 43869 & $0.02 \%$ & & & & & \\
\hline HS17 & 6000432 & $6.57 \%$ & 2811000 & $1.33 \%$ & & & & & \\
\hline HS18 & 763391 & $0.84 \%$ & 115100 & $0.05 \%$ & & & & & \\
\hline Total & 83847035 & $91.76 \%$ & 5482861 & $2.60 \%$ & Total & 4109508 & $4.50 \%$ & 5833223 & $2.77 \%$ \\
\hline
\end{tabular}

Source: own processing, 2019.

Table 8

Uzbek agrarian trade commodity structure in 2018 (traditional product mapping approach) in USD

\begin{tabular}{|c|c|c|c|c|c|c|c|c|c|}
\hline \multicolumn{10}{|c|}{ All trade transactions worldwide 2018} \\
\hline B-2018 & Import & Share in import & Export & Share in export & A-2018 & Import & Share in import & Export & Share in export \\
\hline & & & & & HSO4 & 6306013 & $0.37 \%$ & 11519642 & $1.04 \%$ \\
\hline & & & & & HS07 & 46876707 & $2.76 \%$ & 307714084 & $27.69 \%$ \\
\hline & & & & & HS08 & 25303500 & $1.49 \%$ & 543935423 & $48.95 \%$ \\
\hline & & & & & HS13 & 2297119 & $0.14 \%$ & 23681603 & $2.13 \%$ \\
\hline & & & & & HS14 & 50530 & $0.00 \%$ & 432113 & $0.04 \%$ \\
\hline & & & & & HS20 & 14786471 & $0.87 \%$ & 30727553 & $2.77 \%$ \\
\hline & & & & & HS22 & 4135961 & $0.24 \%$ & 13253219 & $1.19 \%$ \\
\hline & & & & & Total & 99756301 & $5.87 \%$ & 931263637 & $83.80 \%$ \\
\hline D-2018 & Import & Share in import & Export & Share in export & C-2018 & Import & Share in import & Export & Share in export \\
\hline HS01 & 75001264 & \begin{tabular}{|l|}
$4.41 \%$ \\
\end{tabular} & 2603732 & $0.23 \%$ & & & & & \\
\hline HSO2 & 18641325 & $1.10 \%$ & 40035 & $0.00 \%$ & & & & & \\
\hline $\mathrm{HSO3}$ & 5850531 & $0.34 \%$ & 638303 & $0.06 \%$ & & & & & \\
\hline HS05 & 19823595 & $1.17 \%$ & 5921220 & $0.53 \%$ & & & & & \\
\hline HSO6 & 37106855 & $2.18 \%$ & 4520133 & $0.41 \%$ & & & & & \\
\hline HS09 & 51046497 & $3.00 \%$ & 11483346 & $1.03 \%$ & & & & & \\
\hline HS10 & 305594848 & $17.98 \%$ & 20569994 & $1.85 \%$ & & & & & \\
\hline HS11 & 132548155 & $7.80 \%$ & 70111379 & $6.31 \%$ & & & & & \\
\hline HS12 & 85136376 & $5.01 \%$ & 31814015 & $2.86 \%$ & & & & & \\
\hline HS15 & 238216058 & $14.01 \%$ & 1918960 & $0.17 \%$ & & & & & \\
\hline HS16 & 2376474 & $0.14 \%$ & 13480 & $0.00 \%$ & & & & & \\
\hline HS17 & 347426508 & $20.44 \%$ & 4794369 & $0.43 \%$ & & & & & \\
\hline HS18 & 45450239 & $2.67 \%$ & 6182092 & $0.56 \%$ & & & & & \\
\hline HS19 & 35507175 & $2.09 \%$ & 4877633 & $0.44 \%$ & & & & & \\
\hline HS21 & 48021765 & $2.82 \%$ & 764354 & $0.07 \%$ & & & & & \\
\hline HS23 & 132538363 & $7.80 \%$ & 4705420 & $0.42 \%$ & & & & & \\
\hline HS24 & 20008873 & $1.18 \%$ & 9047084 & $0.81 \%$ & & & & & \\
\hline Total & 1600294901 & $94.13 \%$ & 180005549 & $16.20 \%$ & & & & & \\
\hline
\end{tabular}

Source: own processing, 2019.

Table 9

Uzbek agrarian trade commodity structure by CIS countries in 2018

(traditional product mapping approach) in USD

\begin{tabular}{|c|c|c|c|c|c|c|c|c|c|}
\hline \multicolumn{10}{|c|}{ Trade transactions by CIS countries 2018} \\
\hline B-2018 & Import & Share in import & Export & Share in export & A-2018 & Import & Share in import & Export & Share in export \\
\hline & & & & & HS05 & 298730 & \begin{tabular}{|l|l}
$0.03 \%$ \\
\end{tabular} & 967509 & $0.13 \%$ \\
\hline & & & & & HS06 & 181054 & $0.02 \%$ & 4399916 & $0.60 \%$ \\
\hline & & & & & HS07 & 25368716 & $2.16 \%$ & 159678854 & $21.82 \%$ \\
\hline & & & & & HS08 & 1054224 & $0.09 \%$ & 487262332 & $66.58 \%$ \\
\hline & & & & & HS09 & 1805370 & $0.15 \%$ & 5837989 & $0.80 \%$ \\
\hline & & & & & HS14 & 2529 & $0.00 \%$ & 313027 & $0.04 \%$ \\
\hline & & & & & HS20 & 10499936 & $0.89 \%$ & 20893587 & $2.85 \%$ \\
\hline & & & & & HS22 & 1336916 & $0.11 \%$ & 12722868 & $1.74 \%$ \\
\hline & & & & & HS24 & 3051523 & $0.26 \%$ & 4815777 & $0.66 \%$ \\
\hline & & & & & Total & 43598998 & $3.71 \%$ & 696891859 & $95.22 \%$ \\
\hline D-2018 & Import & Share in import & Export & Share in export & C-2018 & Import & Share in import & Export & Share in export \\
\hline HS01 & 28643144 & \begin{tabular}{|c|}
$0.14 \%$ \\
\end{tabular} & 995059 & \begin{tabular}{|l|l|}
$0.14 \%$ \\
\end{tabular} & & & & & \\
\hline $\mathrm{HSO2}$ & 10559437 & $0.00 \%$ & & $0.00 \%$ & & & & & \\
\hline $\mathrm{HSO3}$ & 1065803 & $0.00 \%$ & 1820 & $0.00 \%$ & & & & & \\
\hline
\end{tabular}




\begin{tabular}{|c|c|c|c|c|c|l|l|l|l|} 
HS04 & 12027581 & $0.22 \%$ & 1610161 & $0.22 \%$ & & & & & \\
\hline HS10 & 301620277 & $0.06 \%$ & 420697 & $0.06 \%$ & & & & & \\
\hline HS11 & 128502892 & $0.01 \%$ & 67855 & $0.01 \%$ & & & & & \\
\hline HS12 & 64648547 & $1.91 \%$ & 13967112 & $1.91 \%$ & & & & & \\
\hline HS13 & 301657 & $0.00 \%$ & & $0.00 \%$ & & & & & \\
\hline HS15 & 192952729 & $0.26 \%$ & 1910610 & $0.26 \%$ & & & & & \\
\hline HS16 & 1262824 & $0.00 \%$ & 10556 & $0.00 \%$ & & & & & \\
\hline HS17 & 248918994 & $0.57 \%$ & 4196115 & $0.57 \%$ & & & & & \\
\hline HS18 & 27232210 & $0.74 \%$ & 5391381 & $0.74 \%$ & & & & & \\
\hline HS19 & 32368597 & $0.55 \%$ & 4011230 & $0.55 \%$ & & & & & \\
\hline HS21 & 33261013 & $0.08 \%$ & 561902 & $0.08 \%$ & & & & & \\
\hline HS23 & 47981621 & $0.25 \%$ & 1852910 & $0.25 \%$ & & & & & \\
\hline Total & 1131347326 & $4.78 \%$ & 34997408 & $4.78 \%$ & & & & & \\
\hline
\end{tabular}

Source: own processing, 2019.

Agricultural trade as well as the entire agricultural sector went through a significant restructuring process. The production and trade structures recorded important changes. But the transformation of the Uzbek agrarian sector has not yet finished the restructuring process, and its commodity profile is constantly changing. Low added-value products (very low unit value) still represent a significant share of total exports. The value of Uzbek agrarian trade is typical primarily because of its specific character in relation to individual partners/partner territories. As already mentioned, Uzbek agrarian trade is focused on the CIS, Asia and Europe. In the analyzed time period (2000 - 2018), a significant increase in the value of exports and imports can be observed in relation to all the main territories representing the main Uzbek trading partners in the agricultural sector (Asian countries - export value growth of more than $1700 \%$, CIS countries - export value growth of $250 \%$ ). As noted above, a negative feature of Uzbek agrarian trade is a much higher relative increase in the value of imports compared to the value of exports. This tendency was seen in several key areas under the analysis (CIS, EU28, Latin America, North America, Other European countries). The only region - Asian countries (without CIS) recorded the growth of positive export/import coverage ratio.

Uzbekistan's problem is the rather limited heterogeneity of export competitiveness (aggregations HS07 and HS08 represent the key pillar of agri-food export activities). An analysis of comparative advantages based on the LFI index confirmed the existence of comparative advantages at the bilateral level, especially in relation to post-Soviet countries (the most important partners are the Russian Federation, Kazakhstan and the CIS countries), only in the case of a limited number of trade items. The results presented by the product mapping approach provide a more accurate overview of the distribution of the comparative advantages of Uzbekistan's agrarian exports. Most of the items representing the agrarian trade commodity structure are distributed between two groups, A (with comparative advantages: HS05, HS07, HS08, HS13, HS14, HS20) and D (without comparative advantages: HS01, HS02, HS03, HS04, HS06, HS09, HS10, HS11, HS15, HS16, HS17, HS18, HS19, HS21, HS23). The problem of Uzbek agrarian trade is its extreme commodity concentration. Just aggregations included into quadrant A represent nearly $94 \%$ of total export value. Uzbekistan has been suffering because of constantly decreasing competitiveness of individual trade items and the number of competitive aggregations is constantly decreasing as it could be demonstrated through the last two decades development (for details see Tables 6 - 9). Those changes can be considered as an evidence of an ongoing restructuring process. The commodity structure is still looking for the optimal state. The Republic of Uzbekistan is not competitive at the general level, but rather it has only bilateral comparative advantages, as previously mentioned. Comparative advantages exist, especially with regard to trading partners who apply restrictive trade policies in relation to the world market. Mutual trade is the result not of real price competitiveness, but of political deals. 


\section{Distribution of comparative advantages in relation to different groups of countries}

The Republic of Uzbekistan, as a member of the CIS, carries out its agrarian and trade activities in various regimes and different conditions with respect to certain groups of countries. As a CIS member, Uzbekistan can operate within the CIS market without any restrictions; on the other hand, with respect to some territories, such as other European countries and the EU, the agrarian trade of Uzbekistan is influenced by multilateral agreements signed under the WTO rules, as well as signed at the bilateral level between individual members of the CIS and the EU. If we want to understand the real distribution of comparative advantages, we need to analyze them for each individual group of countries - Asia (without CIS countries), other European countries (without members of the EU28 and CIS), EU28 and CIS countries, North American countries, and the whole world. The analysis provides for a comparison not only of different commodity structures and the competitiveness of individual items for individual groups of countries, but also of the state of the product structure at the beginning and end of the analyzed period. The results obtained from individual analyses provide a very interesting overview of the current and historical situation. Significant dynamics of commodity structure development can be seen in relation to both the LFI and TBI indices. The structure of agrarian trade has not yet been stabilized, and agricultural trade is still looking for the ideal state. Significant changes in the competitiveness of Uzbek agrarian trade in the period from 2000 to 2018 can be observed, especially in relation to the Asian countries, other European countries, CIS countries, African countries and EU28 countries.

According to the product mapping matrix, the share of Group A products in the total volume of agricultural exports increased significantly between 2000 and 2018 (for details, see tables 11 and 13). On the other hand, the proportion of items located in group D was significantly reduced. Developing countries have not changed their role in Uzbek agrarian trade activities, in the case of both exports and imports. The TBI and LFI indices did not show any important changes.

The Republic of Uzbekistan is largely focused on trade activities carried out in relation to developed and, especially, Asian countries and the CIS (for details, see tables 11 and 13).

Table 10

Uzbek agrarian trade value commodity structure - modified product mapping approach (2000)

\begin{tabular}{|c|c|c|c|c|c|c|c|c|c|c|}
\hline \multirow{2}{*}{ Value 2000 (in USD) } & \multicolumn{2}{|c|}{ A } & \multicolumn{2}{|c|}{$\mathrm{B}$} & \multicolumn{2}{|c|}{$\mathrm{C}$} & \multicolumn{2}{|c|}{$\mathrm{D}$} & \multicolumn{2}{|c|}{ Total } \\
\hline & Export & Import & Export & Import & Export & Import & Export & Import & Export & Import \\
\hline Asia & 17.145 .252 & $\begin{array}{r}1.680 .46 \\
8\end{array}$ & 921.768 & $\begin{array}{r}1.116 .92 \\
5\end{array}$ & & & 610.303 & 32.945 .937 & 18.677 .323 & 35.743 .330 \\
\hline Africa & & & & & & & & & & \\
\hline EU 28 & 10.634 .005 & $\begin{array}{r}1.887 .06 \\
8\end{array}$ & $\begin{array}{r}6.955 .54 \\
4\end{array}$ & $\begin{array}{r}4.908 .15 \\
9\end{array}$ & & & 159.471 & $\begin{array}{r}135.142 .08 \\
6\end{array}$ & 17.749 .020 & $\begin{array}{r}141.937 .31 \\
3\end{array}$ \\
\hline $\begin{array}{l}\text { Other European } \\
\text { countries }\end{array}$ & 3.092 .328 & & & & & & 476 & 336.619 & 3.092 .804 & 336.619 \\
\hline CIS & $\begin{array}{r}199551 \\
201\end{array}$ & $\begin{array}{r}3415 \\
916\end{array}$ & & & $\begin{array}{r}5833 \\
223\end{array}$ & $\begin{array}{r}4109 \\
508\end{array}$ & $\begin{array}{r}5482 \\
861\end{array}$ & 83847035 & $\begin{array}{r}210867 \\
285\end{array}$ & 91372459 \\
\hline North America & 2.181 .042 & 15.374 & & & & & & 1.778 .233 & 2.181 .042 & 1.793 .607 \\
\hline Latin America & & & & & & & & & & \\
\hline Australia and Oceania & & & & & & & & & & \\
\hline World & $\begin{array}{l}232603 \\
828\end{array}$ & $\begin{array}{l}6998 \\
826\end{array}$ & $\begin{array}{l}7877 \\
312\end{array}$ & $\begin{array}{l}6025 \\
084 \\
\end{array}$ & $\begin{array}{l}5833 \\
223\end{array}$ & $\begin{array}{l}4109 \\
508\end{array}$ & $\begin{array}{l}6253 \\
111\end{array}$ & $\begin{array}{l}254049 \\
910\end{array}$ & $\begin{array}{l}252567 \\
474\end{array}$ & $\begin{array}{l}271183 \\
328\end{array}$ \\
\hline
\end{tabular}

Source: own processing, 2019. 
Table 11

Uzbek agrarian trade value commodity structure - modified product mapping approach

by CIS countries (2000)

\begin{tabular}{|c|c|c|c|c|c|c|c|c|c|c|}
\hline \multirow{2}{*}{ Value 2000 (in USD) } & \multicolumn{2}{|c|}{ A } & \multicolumn{2}{|c|}{$\mathrm{B}$} & \multicolumn{2}{|c|}{$\mathrm{C}$} & \multicolumn{2}{|r|}{$\mathrm{D}$} & \multicolumn{2}{|c|}{ Total } \\
\hline & Export & Import & Export & Import & Export & Import & Export & Import & Export & Import \\
\hline \multicolumn{11}{|l|}{ Azerbaijan } \\
\hline \multicolumn{11}{|l|}{ Armenia } \\
\hline Belarus & 7102000 & 73800 & 1200 & 44600 & & & & 62000 & 7103200 & 180400 \\
\hline \multicolumn{11}{|l|}{ Moldova } \\
\hline Georgia & 3091560 & & 417 & & & & 465 & 307985 & 3092442 & 307985 \\
\hline Kazakhstan & 2177200 & 75500 & 42100 & 228100 & & & 12700 & 73177500 & 2232000 & 73481100 \\
\hline Kyrgyzstan & 2471923 & 401325 & 1559932 & 968800 & & & & 13585 & 4031855 & 1383710 \\
\hline Russian Federation & 183447298 & 8153671 & 473530 & 1270185 & 198185 & 969 & 93 & 1659665 & 184119106 & 11084490 \\
\hline \multicolumn{11}{|l|}{ Tajikistan } \\
\hline \multicolumn{11}{|l|}{ Turkmenistan } \\
\hline Ukraine & 1544793 & 149849 & 260689 & 3420244 & & & & & 1805482 & 3570093 \\
\hline CIS & 199834774 & 8854145 & 2337868 & 5931929 & 198185 & 969 & 13258 & 75220735 & 202384085 & 90007778 \\
\hline
\end{tabular}

Source: own processing, 2019.

Table 12

Uzbek agrarian trade value commodity structure - modified product mapping approach (2018)

\begin{tabular}{|c|c|c|c|c|c|c|c|c|c|c|}
\hline Value 2018 (in USD) & \multicolumn{2}{|l|}{$\mathrm{A}$} & \multicolumn{2}{|c|}{$\mathrm{B}$} & \multicolumn{2}{|c|}{$\mathrm{C}$} & \multicolumn{2}{|c|}{$\mathrm{D}$} & \multicolumn{2}{|c|}{ Total } \\
\hline & Export & Import & Export & Import & Export & Import & Export & Import & Export & Import \\
\hline Asia & 336798683 & 34994570 & & & 2812815 & 2315965 & 11086121 & 200363423 & 350697619 & 237673958 \\
\hline Africa & 229802 & & 89163 & 122136 & & & 37867 & 5007847 & 356832 & 5129983 \\
\hline EU 28 & 13558000 & 2820796 & & & 5413156 & 20442610 & 641023 & 167130122 & 19612179 & 190393528 \\
\hline Other European countries & 281193 & & & 5854 & & 7895837 & & & 281193 & 7901691 \\
\hline CIS & 696891859 & 43598998 & & & & & 34997408 & 1131347326 & 731889267 & 1174946324 \\
\hline North America & 2641564 & 262718 & 179209 & 326247 & & & 978 & 4702489 & 2821751 & 5291454 \\
\hline Latin America & & & 35221 & 1621011 & & & & 64509709 & 35221 & 66130720 \\
\hline Australia and Oceania & & & & & & & & & & \\
\hline World & 1050401101 & 81677082 & 303593 & 2075248 & 8225971 & 30654412 & 46763397 & 1573060916 & 1105694062 & 1687467658 \\
\hline
\end{tabular}

Source: own processing, 2019.

Table 13

Uzbek agrarian trade value commodity structure - modified product mapping approach by CIS countries (2018)

\begin{tabular}{|c|c|c|c|c|c|c|c|c|c|c|}
\hline \multirow{2}{*}{$\begin{array}{c}\text { Value } 2018 \text { (in } \\
\text { USD) }\end{array}$} & \multicolumn{2}{|c|}{$\mathrm{A}$} & \multicolumn{2}{|c|}{$\mathrm{B}$} & \multicolumn{2}{|c|}{$\mathrm{C}$} & \multicolumn{2}{|c|}{$\mathrm{D}$} & \multicolumn{2}{|c|}{ Total } \\
\hline & Export & Import & Export & Import & Export & Import & Export & Import & Export & Import \\
\hline Azerbaijan & 75984 & 2194403 & $\begin{array}{c}5012 \\
648\end{array}$ & $\begin{array}{l}291 \\
834\end{array}$ & 418807 & 199411 & 20758 & 15362 & 5528197 & 2701010 \\
\hline Armenia & & & & & & & & & & \\
\hline Belarus & 9089262 & 311957 & 20625 & 21156 & & & 37887 & 21353244 & 9147774 & 21686357 \\
\hline Moldova & & & & & & & & & & \\
\hline Kazakhstan & $\begin{array}{c}400854 \\
383\end{array}$ & $\begin{array}{c}22887 \\
580\end{array}$ & & & & & $\begin{array}{c}10933 \\
174\end{array}$ & 589520786 & $\begin{array}{c}411787 \\
557\end{array}$ & 612408366 \\
\hline Kyrgyzstan & & 13500 & & & $\begin{array}{c}90729 \\
059 \\
\end{array}$ & $\begin{array}{c}1365 \\
300 \\
\end{array}$ & 43523 & 620482 & 90772582 & 1999282 \\
\hline Russian Federation & $\begin{array}{c}184162 \\
820\end{array}$ & $\begin{array}{c}19965 \\
788\end{array}$ & & 2529 & & & 3321773 & 380147769 & $\begin{array}{c}187484 \\
593\end{array}$ & 400116086 \\
\hline Tajikistan & 7038650 & 25422 & & & 3444477 & 346154 & & & 10483127 & 371576 \\
\hline Turkmenistan & 8923819 & 138903 & & & & & 1755376 & 2392642 & 10679195 & 2531545 \\
\hline Ukraine & 10260111 & 272439 & & 31959 & & & 39528 & 132471314 & 10299639 & 132775712 \\
\hline Total & $\begin{array}{c}620405 \\
029\end{array}$ & $\begin{array}{c}45809 \\
992\end{array}$ & $\begin{array}{c}5033 \\
273\end{array}$ & $\begin{array}{l}347 \\
478\end{array}$ & $\begin{array}{c}94592 \\
343\end{array}$ & $\begin{array}{c}1910 \\
865\end{array}$ & $\begin{array}{c}16152 \\
019\end{array}$ & $\begin{array}{c}1126521 \\
599\end{array}$ & $\begin{array}{c}747115 \\
838\end{array}$ & $\begin{array}{c}1764110 \\
720\end{array}$ \\
\hline
\end{tabular}

Source: own processing, 2019 
During the analyzed period, the agrarian trade of Uzbekistan changed its structure. The share of agrarian exports realized under group A increased by 3 percentage points ( $92 \%$ to $95 \%)$. The share of the A group in total imports changed from $2.6 \%$ to $4.8 \%$. Group B decreased its share in total agrarian exports and imports from $3.12 \%$ to $0.03 \%$ and from $2.22 \%$ to $0.12 \%$, respectively. The share of exports and imports realized under group C export decreased from $2.3 \%$ to less than $1 \%$ and import increased from $1.5 \%$ to $1.8 \%$, respectively. Exports and imports realized under group D recorded the following changes: The share of exports in total agrarian exports increased from $2.5 \%$ to $4.2 \%$ and the share of realized imports almost did not change (the shift from $93.7 \%$ to $93.2 \%$ ). The conducted analysis also proved the dominant role of CIS and Asian countries as the main trade partners of the Republic of Uzbekistan. Their cumulative share in agrarian exports and imports is a dominant $98 \%$ respectively $84 \%$. In 2000, their cumulative share in total exports and imports reached only $90 \%$, respectively $46 \%$.

As already mentioned above, the agrarian trade of Uzbekistan is concentrated especially on CIS member countries (however, their share in exports is decreasing). Their share in total Uzbek agrarian exports realized under group A decreased from $85.8 \%$ to $66.3 \%$. On the other hand CIS's share in total Uzbek agrarian exports and imports realized under group D decreased from $87.7 \%$ to $74.8 \%$, respectively decreased from $33 \%$ to $71.9 \%$. The role of CIS member countries in B and C group is marginal.

\section{CONCLUSION}

Analysis of the last nineteen years provides the following results. The agrarian trade of Uzbekistan is continually increasing its value, and the character of both its commodity and territorial structure is changing. The relative value of exports increased three times faster when compared to the value of imports. Unfortunately, the trade balance is still in negative numbers. The problem is primarily the very low added value of Uzbek exports, while the added value of imports is much higher. Another negative feature is the constantly decreasing food self-sufficiency. The agrarian trade territorial structure is becoming more and more concentrated. It makes Uzbek agricultural trade extremely vulnerable and dependent on a limited number of partners (especially the CIS). The commodity structure development is the opposite (a diversification trend was proved). The structure of commodity exports is based mainly on the variety of low added-value items having comparative advantages - notably at the bilateral level. While Uzbek agrarian trade is fairly competitive, notably with respect to Asia and CIS countries, competitiveness towards other territories (European countries, especially developing countries, Latin and North America) is limited. In connection with current and especially future Uzbek agricultural trade, it is necessary to increase the volume of production. The combination of the TBI, LFI and product mapping approach analyses proved the comparative advantage of the following set of aggregates/trade items: fish, plants, meat products, cereals, live animals, vegetable oils, vegetable juices, dairy products, sugar, juices, weaving materials, product shredding, drinks and alcohol.

\section{ACKNOWLEDGEMENT}

The paper is processed with financial support of IGA, FEM, CULS Prague. Grant number 20181018 - Economic specifics of the post-Soviet countries and project NAZV QK1920398 financed by the Ministry of Agriculture of the Czech Republic. 


\section{REFERENCES}

Balassa, B. (1991). Comparative Advantage. Trade Policy and Economic Development, New York University Press, ISBN 0814711677.

Balassa, B. (1965). Trade liberalisation and "revealed" comparative advantage 1. The manchester school, 33(2), 99-123.

Benešová, I., Novotná, Z., Šánová, P., \& Laputková, A. (2016). Economic Comparison of Agricultural Sector of Eurasian Countries-Is There Any Potential for Development Through Economic Cooperation?. AGRIS online Papers in Economics and Informatics, 8(665-2016-45116), 19-31, doi:10.7160/aol.2016.080202

Benešová, I., Novotná, Z., Šánová, P., \& Laputková, A. (2016b). Agriculture of the post-Soviet countries. In L. Smutka (Ed.), Agrarian Perspectives XXV. Global and European Challenges for Food Production, Agribusiness and the Rural Economy, Proceedings of the 25th International Scientific Conference, 14-16 September 2016, Prague, Czech Republic (pp. 41-50). Praha: Czech University of Life Sciences Prague, Faculty of Economics and Management.

Bielik, P., Smutka, L., Svatoš, M., \& Hupkova, D. (2013). Czech and Slovak agricultural foreign trade-two decades after the dissolution. Agricultural economics, 59(10), 441-453. doi:10.17221/26/2013-AGRICECON.

Bilan, Y., Lyeonov, S., Stoyanets, N., \& Vysochyna, A. (2018). The impact of environmental determinants of sustainable agriculture on country food security. International Journal of Environmental Technology and Management, 21(5-6), 289-305.

Borák, J., \& Vacek, T. (2018). Czech foreign wine trade - comparative advantages distribution in relation to the european union. Agris on-Line Papers in Economics and Informatics, 10(3), 31-43, doi:10.7160/aol.2018.100303

Bohr, A. (2004). Regionalism in Central Asia: New geopolitics, old regional order. International Affairs, 80(3), 485-502. https://doi.org/10.1111/j.1468-2346.2004.00394.x

Bose, N. (2005). Endogenous growth and the emergence of equity finance. Journal of Development Economics, 77(1), 173-188. https://doi.org/10.1016/j.jdeveco.2004.03.005

Braha, K., Rajčániová, M., Qineti, A., Pokrivčák, J., \& Lazorčáková, E. (2019). Evidence of spatial price transmission in the case of kosovo. Agris on-Line Papers in Economics and Informatics, 11(1), 3-15, ISSN 1804-1930, doi:10.7160/aol.2019.110101

Cameron, D. R., Orenstein, M. A., Allina-Pisano, J., Breslauer, G., Charap, S., Chasu, I., \& Shulman, S. (2012). PostSoviet Authoritarianism: The Influence of Russia in Its "Near Abroad." Post-Soviet Affairs, 28(1), 1-44. https://doi.org/10.2747/1060-586X.28.1.1

Cieślik, A., Qu, Y., \& Qu, T. (2018). Innovations and Export Performance: Firm Level Evidence from China. Entrepreneurial Business and Economics Review, 6(4), 27-47.

Chiaruttini, M. S. (2014). EU, Russia and the Reshaping of the Post-Soviet Space: An International Trade Analysis. Paper to Be Presented at the 54th European Congress of the European Regional Science Association, 14. St. Petersburg.

Cobanli, O. (2014). Central Asian gas in Eurasian power game. Energy Policy, 68, 348-370. https://doi.org/10.1016/i.enpol.2013.12.027

Connolly, R. (2015). Economic Modernisation in Russia: The Role of the World Trade Organization. European Politics and Society, 16(1), 27-44. https://doi.org/10.1080/15705854.2014.965891

Csaki, C. and Nash, J. (1999). Regional and international trade policy. World Bank. Technical Paper Issue 434, Pages 1116. ISSN 0253-7494.

Dalum, B., Laursen, K., \& Villumsen, G. (1998). Structural change in OECD export specialisation patterns: despecialisation and 'stickiness'. International Review of Applied Economics, 12(3), 423-443. doi:10.1080/02692179800000017.

Fertö, I. (2018). Global agri-food trade competitiveness: Gross versus value added exports. Agris on-Line Papers in Economics and Informatics, 10(4), 39-47, doi:10.7160/aol.2018.100404

Fertő, I. (2017). Economic crisis and the fragility of world wine export. AGRIS on-line Papers in Economics and Informatics, 9(4), 25-32. doi:10.7160/aol.2017.090403

Furusawa, T., \& Konishi, H. (2007). Free trade networks. Journal of International Economics, 72, 310-335. https://doi.org/10.1016/j.jinteco.2006.08.003

Hartwell, C. A. (2013). A Eurasian (or a Soviet) Union? Consequences of further economic integration in the Commonwealth of Independent States. Business Horizons, 56(4), 411-420. 
https://doi.org/10.1016/j.bushor.2013.03.003

Head, K., Mayer, T., \& Ries, J. (2010). The erosion of colonial trade linkages after independence. Journal of International Economics, 81(1), 1-14. https://doi.org/10.1016/i.jinteco.2010.01.002

Ilyina, D. (2016). Review of the agro-food trade policy in the post-Soviet countries 2014-15. FAO, 143-158, ISBN 978-92-5-409116-3.

Ishchukova, N., \& Smutka, L. (2014). The Formation of Russian Agrarian Trade Structure: Inter-industry vs. Intraindustry Trade Activities. Acta Universitatis Agriculturae et Silviculturae Mendelianae Brunensis, 62, č. 6, s. 12931299. ISSN: 1211-8516.

Ishchukova, N., \& Smutka, L. (2013). Comparative advantage: products mapping of the Russian agricultural exports. Agris on-line Papers in Economics and Informatics, 5(665-2016-44954), 13-24.

Jambor, A., Toth, A. T., \& Koroshegyi, D. (2017). The Export Competitiveness of Global Cocoa Traders. AGRIS on-line Papers in Economics and Informatics, 9(665-2017-2082), 27-37. doi:10.7160/aol.2017.090303

Korosteleva, E. A. (2016). The European Union and Belarus: democracy promotion by technocratic means? Democratization, 23(4), 678-698. https://doi.org/10.1080/13510347.2015.1005009

Kowalczyk, C., \& Wonnacott, R. J. (1992). Hubs and Spokes, and Free Trade in the Americas (No. 9209). London.

Kozlovskyi, S., Baidala, V., Tkachuk, O., \& Kozyrska, T. (2018). Managament of the Sustainable Development of the Agrarian Sector of the Regions of Ukraine. Montenegrin Journal of Economics, 14(4), 175-190.

Lafay, G. (1992). The measurement of revealed comparative advantages. In: DAGENAIS, M. G. and MUET, P. A. (eds.), London: International Trade Modeling, Chapman \& Hill, pp. 209-234.

Linn, J. (2012). Central Asian Regional Integration and Cooperation: Reality or Mirage? In EDB Eurasian Integration Yearbook 2012 (1st ed., pp. 96-117). Almaty: Eurasian Development Bank.

Maitah, M., Řezbová, H., Smutka, L., \& Tomšík, K. (2016). European sugar production and its control in the world market. Sugar Tech, 18(3), 236-241. doi: 10.1007/s12355-016-0439-9.

Mazhikeyev, A., \& Edwards, T. H. (2013). Central Asian Trade Relations in the Post-Soviet Era. (No. 2013 - 02). Loughborough.

Mazhikeyev, A., Edwards, T. H., \& Rizov, M. (2015). Openness and isolation: The trade performance of the former Soviet Central Asian countries. International Business Review, 24(6), 935-947. https://doi.org/10.1016/J.IBUSREV.2015.03.001

Myant, M., \& Drahokoupil, J. (2008). International Integration and the Structure of Exports in Central Asian Republics. Eurasian Geography and Economics, 49(5), 604-622. https://doi.org/10.2747/1539-7216.49.5.604

Norling, N., \& Swanström, N. (2007). The Virtues and Potential Gains of Continental Trade in Eurasia. Asian Survey, 47(3), 351-373.

Ortikov, A. \& Vacek, T. (2018). Comparative advantage: products mapping of Uzbekistan's agricultural exports. Agrarian Perspectives XXVII. Food Safety - Food Security, Proceedings of the 27th International Scientific Conference, 1920 September 2018, Prague, Czech Republic 2018 pp.203-209.

Puga, D. (2001). European Regional Policies in Light of Recent Location Theories (No. 2767). Toronto.

Remeikiene, R., Gaspareniene, L., \& Volkov, A. (2018). Evaluation of the Influence of the Export in Agricultural Products on the Baltic States Economic Growth. Montenegrin Journal of Economics, 14(3), 83-94.

Rezbová, H., Smutka, L., Pulkrábek, J., \& Benesová, I. (2014). European Sugar factories, Sugar Companies and their Alliances: Who is in Control of European Sugar Market?. Listy cukrovarnicke a reparske, 130(11), 365.

Smutka, L., Benešová, I., \& Laputková, A. (2015a). Agricultural market of post-Soviet countries and its comparison with selected group of countries. In Agrarian Perspectives XXIV. Global Agribusiness and the Rural Economy, Proceedings of the 24th International Scientific Conference, 16-18 September 2015, Prague, Czech Republic (pp. 376-384). Czech University of Life Sciences Prague, Faculty of Economics and Management..

Smutka, L., Steininger, M., Maitah, M., \& Škubna, O. (2015b). The Czech agrarian foreign trade-ten years after the EU accession. In Agrarian Perspectives XXIV. Global Agribusiness and the Rural Economy, Proceedings of the 24th International Scientific Conference, 16-18 September 2015, Prague, Czech Republic (pp. 385-392). Czech University of Life Sciences Prague, Faculty of Economics and Management.

Spechler, M. C., \& Spechler, D. R. (2013). Russia's lost position in Central Eurasia. Journal of Eurasian Studies, 4(1), 17. https://doi.org/10.1016/j.euras.2012.08.001 
Svatoš, M., \& Smutka, L. (2010). Development of agricultural foreign trade in the countries of Central Europe. Agricultural Economics, 56(4), 163-175. doi: 10.17221/22/2010-AGRICECON.

Svatoš, M., \& Smutka, L. (2012). Development of agricultural trade and competitiveness of the commodity structures of individual countries of the Visegrad Group. Agricultural Economics, 58(5), 222-238. doi: 10.17221/51/2011-AGRICECON.

Veebel, V., \& Markus, R. (2018). The bust, the boom and the sanctions in trade relations with Russia. Journal of International Studies, 11(1), 9-20. doi:10.14254/2071-8330.2018/11-1/1

Wajda-Lichy, M., \& Kawa, P. (2018). Trade-Finance Nexus: Was it Distorted in the Aftermath of the Global Financial Crisis?. Entrepreneurial Business and Economics Review, 6(3), 11-27.

Widodo, T. (2009). Comparative advantage: theory, empirical measures and case studies. Review of Economic and Business Studies (REBS), (4), 57-82..

Yun, Y., \& Park, K. (2012). An Analysis of the Multilateral Cooperation and Competition between Russia and China in the Shanghai Cooperation Organization: Issues and Prospects. Pacific Focus, 27(1), 62-85. https://doi.org/10.1111/j.1976-5118.2012.01076.x

Zaghini, A. (2003). Trade advantages and specialization dynamics in acceding countries, Frankfurt am Main, Germany, European central bank, 4-15. 